\title{
Evidence of factorial validity and accuracy of attitudes in mental health scale
}

\author{
Evidências de validade fatorial e precisão da \\ escala de atitudes em saúde mental
}

\author{
Patrícia Fonseca de SOUSA ${ }^{1}$ \\ Silvana Carneiro MACIEL $^{1}$ \\ Ana Raquel Rosas TORRES ${ }^{1}$ \\ Tiago Jessé Souza de LIMA² \\ Katruccy Tenório MEDEIROS ${ }^{1}$ \\ Giselli Lucy Souza VIEIRA ${ }^{1}$
}

\begin{abstract}
This study gathered evidence of factorial validity and internal consistency of the Attitudes in Mental Health Scale. Two studies were performed. A total of 404 college students, including women (69.6\%) with a mean age of 24 years (Standard Deviation $=5.67$ ), participated in Study 1. A total of 396 college students, including females $(69.9 \%)$ with a mean age of 23 years (Standard Deviation $=5.41$ ), participated in Study 2 . In the first study, an exploratory factorial analysis indicated the existence of two factors (biomedical paradigm, $\alpha=0.71$; psychosocial paradigm, $\alpha=0.66$ ) with a total of 15 items. In the second study, a confirmatory factorial analysis indicated that the bifactorial model that was proposed for the scale was adequate: $\chi^{2} / d f=2.41, \mathrm{GFI}=0.93$ and RMSEA $=0.06,90 \% \mathrm{IC}[0.05-0.07]$. The results concluded that this measure can be adequately applied in studies in the proposed measurement context.
\end{abstract}

Keywords: Attitudes scale; Mental health; Test reliability; Test validity.

\section{Resumo}

Esta pesquisa objetivou reunir evidências de validade fatorial e de consistência interna da Escala de Atitudes em Saúde Mental. Foram realizados dois estudos. No Estudo 1 participaram 404 universitários, a maioria do sexo feminino (69,6\%), com idade média de 24 anos (Desvio-Padrão = 5,67). No Estudo 2 participaram 396 universitários, a maioria do sexo feminino (69,9\%), com idade média de 23 anos (Desvio-Padrão =5,41). No primeiro estudo, análises fatoriais exploratórias indicaram a existência de dois fatores (paradigma biomédico, $\alpha=0,71$; paradigma psicossocial, $\alpha=0,66$ )

\footnotetext{
$\checkmark v \nabla v$

1 Universidade Federal da Paraíba, Centro de Ciências Humanas Letras e Artes, Programa de Pós-Graduação em Psicologia Social. Cidade Universitária, Castelo Branco, 58059-900, João Pessoa, PB, Brasil. Correspondência para/Correspondence to: P.F. SOUSA. E-mail: <patriciasousa20@yahoo.com.br>.

2 Universidade de Fortaleza, Departamento de Psicologia. Fortaleza, Ceará, Brasil.

Article based on the master's thesis of P.F. SOUSA, entitled "Adesão à reforma psiquiátrica e preconceito frente ao doente mental: um estudo com universitários à luz da teoria das representações sociais”. Universidade Federal da Paraíba, 2014.

Support: Coordenação de Aperfeiçoamento de Pessoal de Nível Superior.
} 
com 15 itens no total. No segundo estudo, uma análise fatorial confirmatória indicou que o modelo bifatorial proposto para a escala era adequado: $\chi^{2} / d f=2,41, \mathrm{GFI}=0,93$ e $R M S E A=0,06,90 \% / C[0,05-0,07]$. Concluiu-se que essa medida pode ser empregada adequadamente em pesquisas, no contexto de mensuração a que se propõe.

Palavras-chave: Escala de atitudes; Saúde mental; Precisão do teste; Validade do teste.

The field of mental health has undergone significant paradigm shifts. In the middle of the last century, people with psychological distress were segregated from society and locked up in mental hospitals, with a treatment based on prejudice and human rights violations. In the 1970s, psychiatric reform emerged in Brazil; it entailed a movement in which criticisms of this excluding and segregating assistencialist model were prevalent. However, Brazilian psychiatric reform gained strength in the 1980 s as different social participants joined the struggle, including service users, family members, health professionals and society. These social participants joined the discussions and consolidated the struggle for humanized mental health care (Simões, Fernandes, \& Aiello-Vaisberg, 2013).

This new model of mental health care, as recommended by psychiatric reform, focuses on an investment in greater autonomy and independence for persons with psychological distress who seek psychosocial rehabilitation. Thus, a new method for producing care, which is characterized by the search to overcome the biomedical care paradigm to mental health and the establishment of the psychosocial paradigm, is developed (Hirdes, 2009).

Mondoni and Costa-Rosa (2010) note that the paradigms of the mental health field can be understood from four dimensions: (a) the conception of the health-disease process and the theoretical means sustained to address this process; (b) the forms of the organization of intrainstitutional relations; (c) the relationship of the institution and its agents with customers and the general population; (d) and the typical effects of the institution in terms of treatment performance and ethics, i.e., how the forms of relationships between the subject and the socioeconomic and cultural factors of falling ill are produced in exchange for health care actions (Bertolino Neto,

98 2011).
The biomedical paradigm and the psychosocial paradigm differ according to how they approach each of the presented dimensions. The biomedical paradigm can be understood as the classic form of treatment of individuals with mental disorders. It is characterized by the work centered on the doctor figure, whereas other professionals are considered as secondary/auxiliary by the emphasis on organic determinations of problems (diseases) and drug therapy. In addition, the biomedical paradigm operates with the exclusion of family members and users from any participation in the treatment process. Under this paradigm, the psychiatric hospital is the most appropriate place for treatment; however, it functions as a place of deposit and mentoring (Borges \& Luzio, 2010; Maciel, 2007; Rabelo \& Torres, 2005).

Conversely, the psychosocial paradigm corresponds to the set of practices that seek to overcome the biomedical paradigm by ideological opposition, both in theory and in technique and ethics. This paradigm guides the practices of the psychiatric reform and, according to Costa-Rosa (2006), is characterized by interdisciplinary team work with exchanges among professionals to overcome medical knowledge/power. It employs different therapeutic features, such as psychotherapy, labor therapies, sociotherapies and work cooperatives, and medication; however, medication is not a central aspect of treatment. The paradigm also emphasizes the social integration of the individual, investment in the family and the community. In addition to these issues, the psychosocial paradigm considers the political, biopsychosocial and cultural factors as determinants of madness and proposes the participation of the individual and family members in treatment (Mondoni \& Costa-Rosa, 2010).

Despite advances in the field of mental health, psychiatric reform remains an ongoing process. As a result, the psychiatric care guided by 
the psychosocial model coexists with the permanence of the biomedical model, which is centered on the medicalization and hospitalization in psychiatric institutions (Borges \& Luzio, 2010).

As suggested by several studies, the substitute services, which should work as recommended by psychiatric reform, continue to operate with the same logic of the psychiatric hospital. The study by Jorge, Sales, Pinto, and Sampaio (2010), which was conducted in Centro de Atenção Psicossocial (CAPS, Psychosocial Care Center), revealed that professionals in this institution employed a practice that focused on procedures for prescribing drugs. The research conducted by Fiorati and Saeki (2013) on the effectiveness of the psychosocial paradigm in outpatient services revealed that forms of care in these services continue to reflect clinical medical and drug therapy with a strictly biological character, which devalues the actions of psychosocial rehabilitation.

Because psychiatric reform remains a consolidation process on the national stage, studies of the effectuation of this policy acquire a fundamental character. They provide feedback on this reality, which may be important for implementing changes or strengthening existing practices. As reiterated by Mielke, Kantorski, Jardim, Olschowsky, and Machado (2009), studies aimed at evaluating the context of the reform are important because they serve as potential tools for the effectuation of psychosocial practices.

Given the relevance of studies that address this issue and the lack of measurement tools that enable an assessment in this scenario, the Grupo de Pesquisa em Processos Grupais (Research in Group Processes) of the Universidade Católica de Goiás (Catholic University of Goiás) has developed an instrument for evaluating the position of individuals on the biomedical and psychosocial paradigms of mental health care, which is named the Escala de Atitudes em Saúde Mental (EASM, Attitudes in Mental Health Scale). The original version of this tool (Rabelo, 2003; Rabelo \& Torres, 2005) had 26 items and was validated using a mixed sample of professionals of traditional psychiatric services and alternative services in mental health. The obtained data were subjected to a principal component analysis, which indicated the extraction of two components that explained $33 \%$ of the variance. The first component was named the biological paradigm (Cronbach's alpha $=0.86$ ), and the second component was named the psychosocial paradigm (Cronbach's alpha $=0.76)$.

A second version of the EASM, which was revised and updated, was developed by Castro (2009) to portray the current debate about psychiatric reform. This scale was also validated using a sample of mental health professionals. By analyzing the factorial structure of the scale using a main components factorial analysis, this author noticed that the unifactorial structure was the most appropriate structure, which retained 18 of the 26 items. The observed component was named "position on the psychiatric reform" and had a Cronbach's alpha of 0.70 . Both studies did not include the observed factorial loadings.

To increase the viability of future studies on attitudes about psychiatric reform, this study performed a new validation of the EASM with university population samples. This updated version proposed by Castro (2009) depicts the current debate on psychiatric reform. It is shorter, easier to apply and requires a shorter response time. We have selected a university sample because we believe that attitudes are strong predictors of future behavior (Homer \& Kahle, 1988; Lima, 2000). While university students are in the process of forming opinions, this tool can identify the adherence of this population to the paradigms of mental health care and determine whether their actions are consistent with preconized actions by psychiatric reform. In this manner, these students will have ample time for interventions before they enter the professional sector.

\section{Study 1: Scale validation}

This initial study provides psychometric evidence of factorial validity and internal consistency of the EASM using a sample of university students. 


\section{Method}

A total of 404 university students from public and private universities located in the city of João Pessoa, PB, participated in this research; they took courses of psychology (21.0\%), medicine $(20.0 \%)$, nursing (18.3\%), physical therapy (22.0\%) and law $(18.7 \%)$. The mean age of the participants was 24 years $(S D=5.67) ; 30.4 \%$ of the participants were male, and $69.6 \%$ of the participants were female. The sample was selected by a convenience nonprobabilistic sampling procedure, in which we chose to rely on participants enrolled in courses that can directly impart psychiatric reform via health practices or legal means with regard to the recognition of the individual and human rights of the mentally ill.

\section{Instruments}

Attitudes in Mental Health Scale (EASM): The adapted EASM that was developed by Castro (2009) and originally created by Rabelo (2003) was employed. This scale aims to evaluate the position of individuals on the biomedical and psychosocial paradigms of mental health care, which comprises 18 items. The scale was designed to evaluate two factors. The first factor was named the biomedical paradigm (example item: 'Only a psychiatrist is able to fully diagnose, treat and understand mental illness'). The second factor was named the psychosocial paradigm (example item: 'The mentally ill should be treated in the community'). Because the items reflect general positions on mental health practices, the contents of the items did not have to be adapted to the sample in this study. The respondents were asked to indicate their agreement with the items using a scale that ranged between 1 (fully disagree) to 7 (fully agree).

To characterize the sample, the participants answered a sociodemographic questionnaire that contained questions about age, gender, course and the institution in which they study.

\section{Procedures}

Data collection was conducted in public and

100 private universities in the city of João Pessoa, PB.
Initially, contact was made with the institutions in which we intended to conduct the study via the coordinators of the course, who indicated teachers and arranged the day and time for conducting the data collection; data collection was collectively conducted in the classroom. The individuals who administered the tool were previously trained university students. All respondents were informed about the voluntary participation, the guaranteed anonymity and the lack of right or wrong answers. Data collection began upon notification of these aspects and the acceptance of students to participate as indicated in a signed Informed Consent Form per participant. The average respondent required 15 minutes to complete the research. The requirements related to ethics in research with human beings according to Resolution $n^{\circ}$ 196/96 (Brazil, 1996) of the National Health Council were fulfilled. The study was approved by the Comitê de Ética em Pesquisa - Centro de Ciências da Saúde (Research Ethics Committee of the Health Sciences (enter) of the Universidade Federal da Paraiba, under Protocol n 0350/12.

Data from the scale and the sociodemographic questionnaire were tabulated and analyzed using the Statistical Package for Social Sciences (SPSS) for Windows, version 21.0. Descriptive statistical procedures of sociodemographic data (mean, standard deviation and frequencies) in relation to the scale and a principal component analysis were performed to determine the factorial structure of this instrument. An eigenvalue that is equal to or greater than 1 (Kaiser's criterion), Horn's parallel analysis (1965), the analysis of the graphical representation of eigenvalues (Cattell's criterion) and the interpretability of the extracted components (Garson, 2013) were adopted as criteria for the extraction of components. A varimax rotation method was employed. A value of 0.30 was adopted as the cutoff point for the factorial loading (Matsunaga, 2010). If an item obtained high factorial loadings in one or more components, the item was retained in the component in which it showed a higher load. The internal consistency of the scale was also verified by Cronbach's alpha, with values greater than 0.60 and preferably above 0.70 considered to be acceptable (Nunnally, 1991). 


\section{Results}

Initially, a principal component analysis was performed without fixing the rotation method and the number of components to extract a priori. The Kayser-Meyer-Olkin index (KMO) and Bartlett's Sphericity Test were employed to verify the adequacy of the data to conduct the factorial analysis; both were considered satisfactory: $\mathrm{KMO}=0.79$ and Barlett's Sphericity Test, $\chi^{2}(153)=1077.31$, $p<0.001$ (Hair, Anderson, Tatham, \& Black, 2005).

Based on Kaiser's criterion, in which factors with eigenvalues greater than 1 are extracted (Pasquali, 2012), six components could be initially identified, which explained $55.02 \%$ of the total variance. However, the analysis of the graphical representation of the eigenvalues (Cattell's criterion) suggested the retention of three components as confirmed by a parallel analysis (Horn, 1965), which showed the presence of three components with higher eigenvalues than the randomly generated components.

An additional analysis was performed by setting the extraction of three components. The first component presented an eigenvalue of 3.68 , which explained $20.6 \%$ of the variance and includes six items $(11,13,2,4,15$, and 9), with loads that range between 0.78 and 0.44 . This component gathered items with content concerning the biomedical paradigm. The second component showed an eigenvalue of 1.68 , which explained $9.35 \%$ of the variance and included 8 items $(5,10,12,16,3,6$, 1 , and 18$)$, with factorial loadings that ranged from 0.66 to 0.35 . This component gathered items with content concerning the psychosocial paradigm. The third component presented an eigenvalue of 1.4, which explained $7.9 \%$ of the variance and included four items $(14,7,17$, and 8), with factorial loadings that ranged between 0.65 and 0.54 . The content of these items concerned both paradigms and lacked interpretability. An additional analysis was conducted by fixing the extraction of two components according to the initial proposition of the scale (Rabelo, 2003).

An additional principal component analysis was conducted by dividing the number of components to extract in two using a varimax rotation and adopting a factorial load equal or greater than 0.30 as a criterion for retaining the item in the factor. At this stage, three items were removed for failing to present a saturation greater than 0.30 for any factor: item 8 ('The doctor must work with a team to provide an effective treatment for mental illness'), item 14 ('The family of a mental health service users needs to be in constant contact with the team that accompanies them'), and item 17 ('A detailed history is essential to formulate a diagnostic hypothesis'). An additional principal components analysis was performed with the remaining 15 items (excluding these items) by fixing the extraction of two factors with varimax rotation. The results of this analysis are listed in Table 1.

Component 1, which was interpreted as a biomedical paradigm, yielded an eigenvalue of 3.53, which corresponded to the explanation of $23.5 \%$ of the total variance. It gathered seven items with a saturation that ranged from 0.46 ('It is very dangerous to live with the mental patient at home') to 0.75 ('Only a psychiatrist is able to fully diagnose, treat and understand mental illness'), which legitimizes the hospitalization of mental patients. The reliability of this factor using Cronbach's alpha was 0.71 .

Component 2, which was interpreted as the psychosocial paradigm, yielded an eigenvalue of 1.68 , which explained $11.2 \%$ of the total variance. It gathered eight items with a saturation that ranged from 0.37 ('Mental illness, as well as its treatment, involves more social problems than organic problems') to 0.67 ('The mentally ill should be treated in the community'), which refers to reintegration of the subject with psychological distress via actions of citizenship and family bonding. The reliability of this factor by Cronbach's alpha was 0.66 .

\section{Discussion}

The objective of this study was to provide psychometric evidence of factorial validity and internal consistency of the EASM and to increase 
Table 1

Principal component analysis of the Attitudes in Mental Health Scale (EASM, Escala de Atitudes em Saúde Mental)

\begin{tabular}{|c|c|c|c|}
\hline \multirow{2}{*}{ Items } & \multicolumn{2}{|c|}{ Factorial loadings } & \multirow{2}{*}{$h^{2}$} \\
\hline & 1 & 2 & \\
\hline 11. Only a psychiatrist is able to fully diagnose, treat and understand mental illness. & 0.75 & 0.05 & 0.23 \\
\hline 13. Only psychiatry is the science responsible for treating mental illness. & 0.72 & -0.01 & 0.32 \\
\hline 15. Depression can only be cured via medical treatment. & 0.59 & -0.09 & 0.28 \\
\hline 4. The mentally ill should be isolated when physically aggressive. & 0.55 & -0.19 & 0.33 \\
\hline 2. A doctor should indicate the time of discharge in a mental health treatment. & 0.55 & -0.18 & 0.42 \\
\hline 7. The worker in mental health services should not engage in struggles for greater social rights of the mentally ill. & 0.47 & -0.05 & 0.30 \\
\hline 9. Living with a mentally ill patient at home can be dangerous. & 0.46 & -0.37 & 0.22 \\
\hline 10. The mentally ill should be treated in the community. & -0.22 & 0.67 & 0.49 \\
\hline 5. Psychiatric treatment can only begin with a patient's consent. & 0.02 & 0.65 & 0.55 \\
\hline 12. A patient needs to be home for treatment. & 0.07 & 0.59 & 0.35 \\
\hline 3. Study, work and social life are essential in the treatment of schizophrenia. & -0.11 & 0.52 & 0.51 \\
\hline 16. A patient can determine the time of hospital discharge. & -0.16 & 0.51 & 0.35 \\
\hline 1. Participation in associations and/or clubs in favor of citizenship is a right of the mentally ill. & -0.21 & 0.44 & 0.28 \\
\hline 6. Social ties can treat a psychiatric patient. & -0.35 & 0.43 & 0.13 \\
\hline 18. Mental illness and its treatment involves more social problems than organic problems. & -0.02 & 0.37 & 0.12 \\
\hline Number of items & 7 & 8 & \\
\hline Eigenvalue & 3.62 & 1.68 & \\
\hline$\%$ of explained variance & 23.5 & 11.2 & \\
\hline Cronbach's alpha & 0.71 & 0.66 & \\
\hline
\end{tabular}

Note: 1: Biomedical paradigm; 2: Psychosocial paradigm; $\mathrm{h}^{2}$ : Communality. Bold numbers indicate the items retained for each factor.

the viability of future studies on attitudes on psychiatric reform. Based on the presented results, the bifactorial structure (biomedical paradigm and psychosocial paradigm) of the EASM was the most appropriate structure, which confirmed the factorial structure observed by Rabelo (Rabelo, 2003; Rabelo \& Torres, 2005). Both factors present satisfactory internal consistency indices (Pasquali, 2012). These paradigms are also highlighted in the studies by Costa-Rosa (2006), who proposed them to discuss the practices that guide the care of psychological distress.

The biomedical paradigm, which remains hegemonic in the mental health field, is characterized by cloistering and medicalizing practices and by an action that is centered in the mental illness, which is understood as having an organic foundation. Conversely, the psychosocial paradigm understands that the prospects of care are focused on an investment in greater autonomy and independence of the person with mental illness and seeks a psychosocial resocialization and rehabilitation of these individuals to achieve effective social inclusion (Mondoni \& Costa-Rosa, 2010).

Note that high scores for one of the factors are interpreted as compliance indicators to the biomedical paradigm or the psychosocial paradigm. To determine the extent that the bifactorial model can be replicated in other samples demands a new study.

\section{Study 2: Confirmatory analysis of the EASM}

In this study, the objective was to replicate the factorial structure composed of two factors: the first factor, which is named the biomedical paradigm, consists of seven items; the second factor, which is named the psychosocial paradigm, consists of eight items. A confirmatory factorial analysis was performed. In addition, we compared the adjustment of the bifactorial model observed in Study 1 and in studies by Rabelo (Rabelo, 2003; Rabelo \& Torres, 2005) with an alternative unifactorial model obtained by Castro (2009). 


\section{Method}

A total of 396 university students from public and private universities located in the city of João Pessoa, PB, participated in this study; they were distributed among the courses of psychology (18.9\%), medicine (19.9\%), nursing (21.7\%), physical therapy (17.9\%) and law (21.6\%). The age of the participants was 23 years $(S D=5.41) ; 30.1 \%$ of the participants were male, and $69.9 \%$ of the participants were female. The sample was selected by a non-probabilistic procedure of convenience sampling.

\section{Instruments}

The EASM was employed for data collection. The final version of this scale, as obtained in Study 1, consisted of 15 items divided into two factors: the biomedical paradigm (seven items) and the psychosocial paradigm (eight items). The respondents were asked to indicate their agreement with the items using a scale that ranged from 1 (fully disagree) to 7 (fully agree).

\section{Procedures}

The procedure and ethical aspects described in Study 1 were employed. A confirmatory factorial analysis, which was aimed at replicating the factorial structure in Study 1, was conducted. The maximum likelihood estimation method, which uses the matrix of variance-covariance, was employed. The missing cases $(0.04 \%$ of the responses) were replaced by the mean. To test the adequacy of the model, the following indexes were employed: the ratio between the Chi-square and the degrees of freedom $\left(\chi^{2} / d f\right)$, with values between 2 and 3 , which indicate an acceptable adjustment; the Goodness-of-Fit Index (GFI) and the Root Mean Square Error of Approximation (RMSEA), in which values near 0.95 and 0.06 , respectively, indicate an acceptable adjustment (Byrne, 2010). GFI values greater than 0.90 and RMSEA values less than 0.08 are indicators of acceptable adjustment (Byrne, 2010; Garson, 2012). In addition to these indicators, the Chi-square difference $\left(\Delta \chi^{2}\right)$ and the Expected Cross-Validation Index (ECVI) were employed to assess improvements among the tested competing models. Significant values of $\Delta \chi^{2}$ and lower values of ECVI reflect a model with better adjustment (Garson, 2012). Analyses were performed using AMOS software (version 18). Data from the sociodemographic questionnaire were analyzed using the SPSS for Windows, version 21.0, and descriptive statistics (frequencies and percentages).

\section{Results}

A confirmatory factorial analysis was initially performed to test the adjustment of the bifactorial model (Model 1) proposed in Study 1. This model produced acceptable adjustment indices, which were similar to the indices recommended by the literature: $\chi^{2}(89)=234.3, \chi^{2} / \mathrm{df}=2.63, \mathrm{GFI}=0.92$ and RMSEA $=0.064,90 \%$ Confidence Interval $(90 \% \mathrm{Cl})[0.054-0.074], \mathrm{ECVI}=0.750$. The adjustment of this model was compared with an alternative unifactorial model, which yielded adjustment indices that were less than the indices observed in the bifactorial model: $\chi^{2}(90)=354.65$, $\chi^{2} / \mathrm{df}=3.94, \mathrm{GFI}=0.88$ and RMSEA $=0.086,90 \% \mathrm{IC}$ [0.077-0.096], ECVI $=1.050$. The $\Delta \chi^{2}$ test revealed a significant difference between these two models: $\Delta \chi^{2}(1)=111.35, p<0.001$. The ECVI in the bifactorial model was significantly less than the ECVI in the unifactorial model, which indicates that this factorial solution is the most appropriate model.

Having opted for the bifactorial model as the most appropriate, an inspection of residue and modification indices was conducted, which suggested a correlation of the measurement errors of items 5 and 16 (Modification Index - MI = 18.7). In addition to belonging to the same factor, these items had a common content (patient's autonomy in making decisions regarding his treatment). The obtained adjustment indices indicate an acceptable adjustment of the proposed factorial structure: $\chi^{2} / \mathrm{df}=2.41, \mathrm{GFI}=0.93$ and $\mathrm{RMSEA}=0.06,90 \% \mathrm{IC}$ [0.05 - 0.07]. The factor structure and the regression weights are shown in Figure 1. All regression weights were significant $(p<0.05)$. Factor 1 , which 


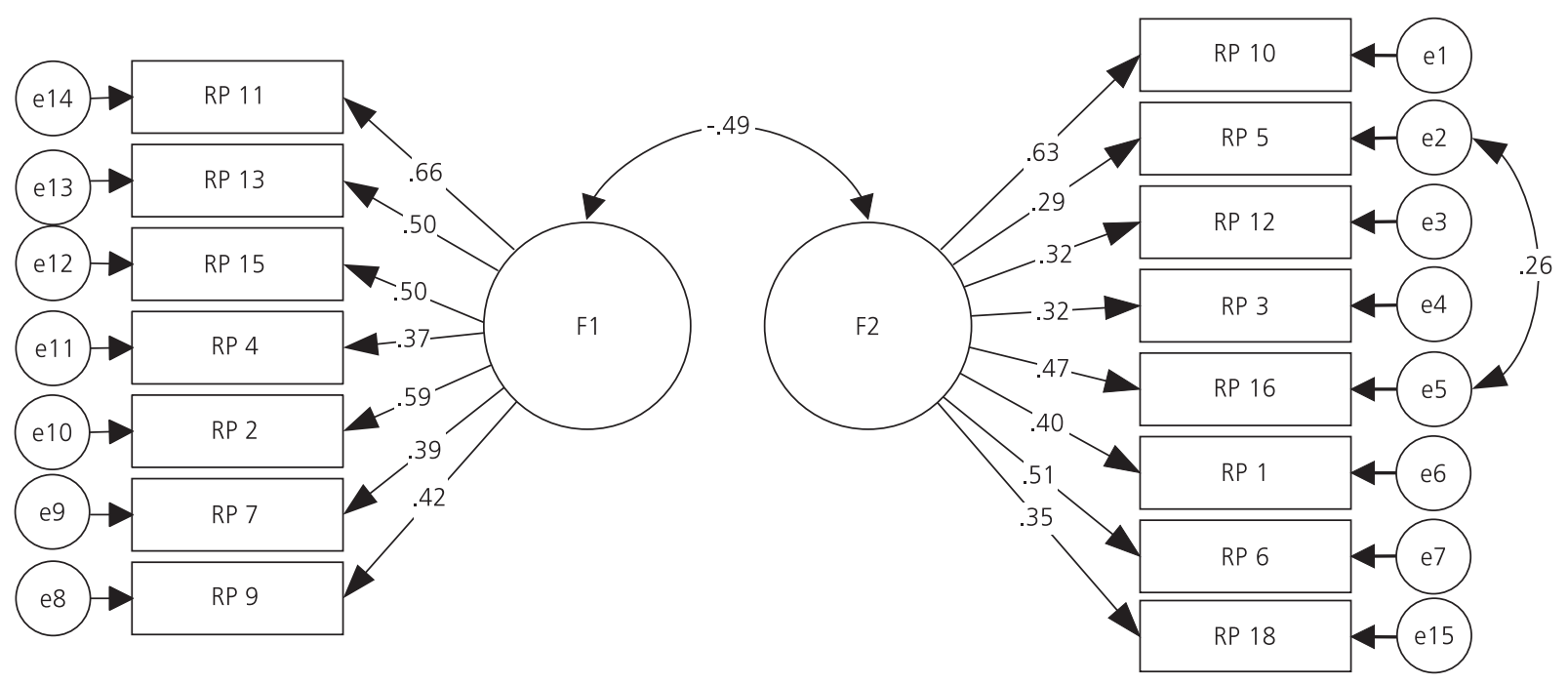

Figure 1. Regression coefficients and correlations of the bifactorial structure of the Attitudes in Mental Health Scale (EASM, Escala de Atitudes em Saúde Mental).

is named the biomedical paradigm, presented a Cronbach's alpha of 0.69 , whereas factor 2, which is named the psychosocial paradigm, presented a Cronbach's alpha of 0.64. As expected, the two factors exhibited a negative correlation.

\section{Discussion}

The objective of this second study was to gather additional evidence of factorial validity and internal consistency of the EASM. The confirmatory factor analysis of the measure noted the appropriateness of the proposed factorial structure, with the obtained adjustment indices within a range that is commonly accepted in the literature (Garson, 2012). The test of alternative explanatory models showed that the bifactorial model, which is proposed by Rabelo (Rabelo, 2003; Rabelo \& Torres, 2005), was the most appropriate model compared with the unifactorial model proposed by Castro (2009).

\section{General Discussion}

The objective of the two studies presented in this paper was to gather evidence of the factorial validity and reliability of the EASM. The findings conclude that these objectives were accomplished. At the end of the two studies, a short tool that consists of 15 items, is self-applicable and presents satisfactory psychometric qualities of factorial validity and internal consistency enables its use in future research.

Possible limitations of the study are not rejected, which highlights, for example, the fact that the sample was very specific (formed by university students) and convenient (non-probabilistic), which limits the generalization of the described results for other sample groups that lack the characteristics of the sample of this research. Note that it was not intended to generalize the results to the entire population but to provide the scientific community with a scale with adequate psychometric properties for the studied population. The presented limitations can limit the power of generalization of the results without invalidating them.

In the initial version, the EASM had 18 items organized along two factors. However, analyses suggested a reduction in the number of items of this scale because their saturation was below the cutoff point of 0.30 in both factors. The new version consisted of 15 items that were distributed in a bifactorial structure with seven items in factor 1 (biomedical paradigm) and eight items in factor 2 (psychosocial paradigm), which confirmed the 
model that was initially proposed by Rabelo and Torres (2005). Both factors showed satisfactory levels of internal consistency that were below the levels noted by Rabelo and Torres (2005). This lower value in relation to internal consistency can be attributed to the used sample, as in the study by Rabelo and Torres (2005), in which the sample included health professionals who probably a greater knowledge and consistency of position about the treatment approaches. Note that Cronbach's alpha tends to be a conservative estimate of the reliability of a measure; therefore, the true estimate of reliability has a low probability of being lower that the reported value and a high probability of being higher than the reported value (Maroco \& Garcia-Marques, 2006).

In Study 2, the bifactorial structure proposed for the EASM was replicated by confirmatory factorial analysis in a different sample, and the obtained adjustment indexes, while not exceptional, can be considered to be favorable by the literature (Byrne, 2010). Study 2 also indicated that the bifactorial model proposed by Rabelo and Torres (2005) has a better adjustment than the unifactorial model obtained in the study by Castro (2009). Thus, the use of this measure is considered to be appropriate for future studies.

Additional studies are recommended to test the factorial validity and internal consistency of the scale in other samples and to provide additional evidence of concurrent and predictive validity. Future studies will also assess attitudes about paradigms of mental illness treatment depending on the psychiatric condition because some studies have shown that attitudes about people with schizophrenia have worsened in the last two decades, whereas attitudes about other conditions, such as depression and alcoholism, have improved or remained stable (Angermeyer, Matschinger, \& Schomerus, 2013). Therefore, the type of psychiatric condition can interfere with attitudes about forms of treatment. Future studies will also assess the relation between beliefs about the origin of mental illness and attitudes about forms of treatment (Schomerus et al., 2012).
According to Borges and Luzio (2010), psychiatric reform remains a process that is under construction; for this reason, the psychiatric care guided by outpatient services coexists with the permanence of the biomedical paradigm, which is centered in hospital psychiatric institutions. The results can significantly contribute to the expansion and strengthening of knowledge about psychiatric reform in an attempt to encourage the consolidation of this policy on the national scene. The EASM may be employed to verify whether future mental health professionals (e.g., psychologists, nurses, and doctors) have attitudes that are congruent with the theoretical principles of psychiatric reform. This evaluation will enable higher education institutions to identify possible gaps in the training of students and address these gaps, for example, by providing more information about mental health (Jorm, 2012) before their students enter the labor market.

\section{Contributors}

All authors contributed to the conception and design of the study, data analysis and final editing.

\section{References}

Angermeyer, M. C., Matschinger, H., \& Schomerus, G. (2013). Attitudes towards psychiatric treatment and people with mental illness: Changes over two decades. The British Journal of Psychiatry, 203(2), 146-151. http://dx.doi.org/10.1192/bjp.bp.112.122978

Bertolino Neto, M. M. (2011). Atenção em saúde mental: identificação e acompanhamento de pessoas com problemas de saúde mental por equipes da Estratégia de Saúde da Família (Dissertação de mestrado nãopublicada). Recuperado em janeiro 20, 2014, de http:// www.teses.usp.br/teses/disponiveis/6/6136/tde12032012-114447/pt-br.php.

Borges, R. F., \& Luzio, C. A. (2010). Pesquisa qualitativa em saúde mental: alguns apontamentos. Revista de Psicologia da UNESP, 9(1), 14-23. Recuperado em janeiro 20, 2014, de http://www2.assis.unesp.br/ revpsico/index.php/revista/article/viewArticle/66

Brasil. Ministério da Saúde. (1996). Resolução n 196/96 sobre pesquisa envolvendo seres humanos. Recuperado em janeiro 20, 2014, de http://bvsms.saude. gov.br/bvs/saudelegis/cns/1996/res0196_10_10_ 1996.html 
Byrne, B. M. (2010). Structural equation modeling with Amos: Basic concepts, applications, and programming. New York: Routledge.

Castro, U. R. (2009). Reforma psiquiátrica e o louco infrator: novas ideias e velhas práticas (Dissertação de mestrado não-publicada). Universidade Católica de Goiás. Recuperado em janeiro 20, 2014, de http:// www.teses.usp.br/teses/disponiveis/6/6136/tde-12 032012-114447/pt-br.php

Costa-Rosa, A. (2006). O modo psicossocial: um paradigma das práticas substitutivas ao modo asilar. In P. Amarante (Ed.), Ensaios, subjetividade, saúde mental e sociedade. Rio de Janeiro: Fiocruz.

Fiorati, R. C., \& Saeki, T. (2013). As dificuldades na construção do modo de atenção psicossocial em serviços extra-hospitalares de saúde mental. Saúde em Debate, 37(97), 305-312. Recuperado em janeiro 20, 2014, de http://www.scielo.br/pdf/sdeb/v37n97/v37n97a12. pdf

Garson, G. D. (2012). Structural equation modeling. Asheboro: Statistical Publishing Associates.

Garson, G. D. (2013). Factor analysis. Asheboro: Statistical Publishing Associates.

Hair, J. F., Anderson, R. E., Tatham, R. L., \& Black, W. C. (2005). Análise multivariada de dados. Porto Alegre: Bookman.

Hirdes, A. (2009). A reforma psiquiátrica no Brasil: uma (re)visão. Ciência \& Saúde Coletiva, 14(1), 297-305. http://dx.doi.org/10.1590/S1413-8123200900010 0036

Homer, P. M., \& Kahle, L. R. (1988). A structural equation test of the value - attitude - behavior hierarchy. Journal of Personality and Social Psychology, 54(4), 638-646. http://dx.doi.org/10.1037/0022-3514.54.4.638

Horn, J. L. (1965). A rationale and test for the number of factors in factor analysis. Psychometrika, 30(2), 179-185. Retrieved April 9, 2014, from http://link.springer.com/ article/10.1007\%2FBF02289447

Jorge, M. S. B., Sales, F. D. A., Pinto, A. G. A., \& Sampaio, J. J. C. (2010). Interdisciplinaridade no processo de trabalho em centro de atenção psicossocial. Revista Brasileira em Promoção de Saúde, 23(3), 221-230. Recuperado em fevereiro 2, 2014, de http://www. redalyc.org/articulo.oa?id=40818208005

Jorm, A. F. (2012). Mental health literacy: Empowering the community to take action for better mental health. American Psychologist, 67(3), 231-243. http://dx.doi. org/10.1037/a0025957

Lima, M. L. P. (2000). Atitudes. In J. Vala \& M. B. Monteiro (Coords.), Psicologia social. Lisboa: Fundação Calouste Gulbenkian.

Maciel, S. C. (2007). Exclusão/inclusão social do doente mental/louco: representações e práticas no contexto da reforma psiquiátrica (Tese de doutorado não-publi- cada). Universidade Federal da Paraíba, João Pessoa. Recuperado em janeiro 20, 2014, de http://www. cchla.ufpb.br/ppgps/index.php?option=com_ content\&view=article \&id=77\&ltemid=99

Maroco, J., \& Garcia-Marques, T. (2006). Qual a fiabilidade do alfa de Cronbach? Questões antigas e soluções modernas. Laboratório de Psicologia, 4(1), 65-90. Recuperado em abril 9, 2015, de http://publicacoes. ispa.pt/index.php/lp/article/viewFile/763/706

Matsunaga, M. (2010). How to factor-analyze your data right: Do's, dont's, and how-to's. International Journal of Psychology Research, 3(1), 97-110. Retrieved April 9, 2015, from http://www.redalyc.org/articulo.oa? id=299023509007

Mielke, F. B., Kantorski, L. P., Jardim, V. M. R., Olschowsky, A., \& Machado, M. S. (2009). O cuidado em saúde mental no CAPS no entendimento dos profissionais. Ciência \& Saúde Coletiva, 14(1), 159-164. http://dx. doi.org/10.1590/S1413-81232009000100021

Mondoni, D., \& Costa-Rosa, A. (2010). Reforma psiquiátrica e transição paradigmática no interior do estado de São Paulo. Psicologia: Teoria e Pesquisa, 26(1), 39-47. http://dx.doi.org/10.1590/S0102-37722010 000100006

Nunnally, J. C. (1991). Teoría psicométrica. México: Trillas.

Pasquali, L. (2012). Análise fatorial para pesquisadores. Brasília: LabPAM.

Rabelo, I. V. M. (2003). Reforma psiquiátrica e bem estar: perspectivas e contradições entre trabalhadores de saúde mental do município de Goiânia (Dissertação de mestrado não-publicada). Universidade Católica de Goiás, Goiânia.

Rabelo, I. V. M., \& Torres, A. R. R. (2005). Trabalhadores em saúde mental: relações entre práticas profissionais e bem-estar físico e psicológico. Psicologia: Ciência e Profissão, 25(4), 614-625. http://dx.doi.org/10.1590/ S1414-98932005000400010

Schomerus, G., Schawahn, C., Holzinger, A., Corrigan, H. J., Grabe, H. J., Carta, M. G., \& Angermeyer, M. C. (2012). Evolution of public attitudes about mental illness: A systematic review and meta-analysis. Acta Psychiatrica Scandinavica, 125(6), 440-452. http://dx. doi.org/10.1111/j.1600-0447.2012.01826.x

Simões, C. H. D., Fernandes, R. A., \& Aiello-Vaisberg, T. M. J. (2013). O profissional de saúde mental na reforma psiquiátrica. Estudos de Psicologia (Campinas), 30(2), 275-282. http://dx.doi.org/10.1590/S0103-166 X2013000200014

Received: February 10, 2015

Final version: June 1, 2015

Approved: June 2, 2015 